\title{
Implementasi Indoor Positioning System Berbasis Smartphone dengan Penambahan Access Point untuk Studi Kasus Gedung Teknik Informatika ITS
}

\author{
Fananda Herda Perdana, R.V. Hari Ginardi, dan F.X. Arunanto \\ Jurusan Teknik Informatika, Fakultas Teknologi Informasi, Institut Teknologi Sepuluh Nopember \\ Arief Rahman Hakim, Surabaya 60111 Indonesia \\ e-mail: hari@its.ac.id
}

\begin{abstract}
Abstrak-Saat ini kebutuhan masyarakat akan informasi lokasi sangat tinggi, terutama dengan memanfaatkan teknologi teknologi GPS. Teknologi GPS saat ini sudah sangat maju untuk mencari tahu lokasi di luar ruangan tetapi untuk di dalam ruangan sistem ini memiliki akurasi yang rendah, apalagi untuk ruangan/gedung yang besar. Oleh karena itu, sebuah sistem yang lebih akurat untuk memberikan solusi bagi pendeteksian lokasi di dalam ruangan atau gedung yang memiliki lebih dari satu level lantai dikembangkan dengan konsep 3D Indoor Positioning System. Untuk meminimalisir penurunan akurasi Indoor Positioning System karena minimnya jumlah access point atau persebaran access point yang kurang merata, maka dalam penelitian ini akan ditambahkan access point di lokasi yang memiliki akses sinyal Wi$F i$ lemah setelah dilakukan evaluasi dari data sampel kondisi terkini access point di Gedung Teknik Informatika. Uji coba dilakukan dengan cara melakukan perbandingan hasil akurasi dari pengujian di beberapa lokasi kampus Teknik Informatika ITS ketika sebelum dilakukan penambahan access point dan ketika sesudah dilakukan penambahan access point. Setelah dilakukan penambahan access point di beberapa titik lokasi yang memiliki cakupan sinyal Wi-Fi lemah, dihasilkan akurasi yang meningkat hingga $16,67 \%$, dari akurasi semula $78,70 \%$ menjadi $\mathbf{9 5 , 3 6 \%}$ untuk seluruh titik uji coba pada gedung kampus. Selain itu juga penambahan access point berhasil meningkatkan akurasi 9 ruangan dari total 23 ruangan yang diuji secara signifikan (meningkat di atas $20 \%$ ), terutama di daerah sekitar penambahan access point.
\end{abstract}

Kata Kunci-Android, Access Point, Aplikasi Perangkat Bergerak, Indoor Positioning, Layanan Berbasis Lokasi, Wi-Fi

\section{PENDAHULUAN}

$\mathrm{D}$ EWASA ini teknologi untuk melacak posisi telah banyak digunakan. Teknologi tersebut menggunakan GPS milik Pemerintah Negara Amerika Serikat. GPS tersebut dapat digunakan untuk mencari posisi sekarang, alamat tempat atau arah ke suatu tempat. Akan tetapi GPS memiliki kekurangan yaitu akurasi yang rendah ketika digunakan di dalam ruangan. Oleh karena itu, teknologi untuk melacak posisi di dalam ruangan indoor mulai dikembangkan dengan konsep Indoor Positioning System.

Beberapa peneliti telah mengembangkan konsep Indoor Positioning System tersebut dengan berbagai variasi cara dan metode untuk memperoleh akurasi yang paling tinggi, seperti clustering KNN (K-Nearest Neighbor), NN (Nearest
Neighbor), teknik triangulasi, teknik trilaterasi, dan sebagainya. Dari penelitian yang sudah ada, clustering KNN menghasilkan akurasi paling tinggi untuk masalah deteksi lokasi, tetapi masih sering terdapat beberapa hasil yang tidak sesuai. Salah satu faktor yang menyebabkan ditemuinya hasil error pada penelitian tersebut adalah jumlah access point yang kurang mencukupi untuk uji coba ataupun persebaran lokasi access point yang tidak merata sehingga mempersulit analisis data.

Dalam tugas akhir ini, Indoor Positioning System berbasis Wi$F i$ akan digunakan untuk menentukan posisi menggunakan kekuatan sinyal dari beberapa $\mathrm{Wi}-\mathrm{Fi}$ yang ada di dalam ruangan. Dalam penelitian ini akan ditambahkan access point di beberapa ruangan yang memiliki kekuatan akses sinyal $\mathrm{Wi}$ $\mathrm{Fi}$ lemah untuk mengantisipasi penurunan akurasi Indoor Positioning System yang disebabkan karena minimnya jumlah access point atau persebaran access point yang kurang merata. Hasil penangkapan sinyal RSSI (Received Signal Strength Indication) akan diproses dengan clustering Filtered K-Nearest Neighbors. Kemudian hasilnya akan dibandingkan dengan hasil percobaan ketika belum ditambahkan access point. Model lokasi yang digunakan adalah Gedung Teknik Informatika ITS.

\section{TINJAUAN PUSTAKA}

\section{A. Location Based Service (LBS)}

Location Based Service atau layanan berbasis lokasi adalah layanan informasi yang dapat diakses dengan perangkat mobile melalui jaringan selular dan memanfaatkan kemampuan untuk menggunakan lokasi pada perangkat mobile [1].

\section{B. Indoor Positiong System (IPS)}

IPS adalah sebuah solusi yang didasari oleh magnetik, data sensor atau perangkat jaringan yang digunakan untuk menemukan suatu benda atau seseorang secara nirkabel di dalam bangunan.

\section{Indoor Positioning Menggunakan Sinyal Wi-Fi}

Pada penelitian sebelumnya, sudah pernah dibuat aplikasi yang menerapkan Indoor Positioning System. Aplikasi ini memiliki kemampuan untuk mendeteksi lokasi pengguna di dalam ruangan dengan menggunakan data kekuatan sinyal $\mathrm{Wi}$ $F i$ yang ditangkap oleh smartphone pada ruangan tersebut. 
Kemudian hasil yang didapatkan adalah informasi lokasi pengguna seperti: nama ruangan atau area lokasi keberadaan pengguna serta tingkat lantai dari lokasi tersebut [2].

Sistem ini sudah dikembangkan pada studi kasus pada Gedung Teknik Informatika ITS. Sistem memberikan performa yang baik untuk seluruh test area pada hampir setiap lokasi uji coba. Tetapi ada beberapa lokasi uji coba yang mendapatkan hasil kurang baik dikarenakan lokasi tersebut tidak tercakup sinyal access point yang memadai.

\section{Android Studio}

Android Studio [3] adalah sebuah IDE untuk Android Development yang diperkenalkan Google pada acara Google I/O 2013. Android Studio merupakan pengembangan dari Eclipse IDE, dan dibuat berdasarkan IDE Java populer, yaitu IntelliJ IDEA. Android Studio merupakan IDE resmi untuk pengembangan aplikasi Android.

Sebagai pengembangan dari Eclipse, Android Studio mempunyai banyak fitur-fitur baru dibandingkan dengan Eclipse IDE. Berbeda dengan Eclipse yang menggunakan Ant, Android Studio menggunakan Gradle sebagai build environment.

\section{E. Microsoft SQL Server}

Microsoft SQL Server [4] adalah sebuah sistem manajemen basis data relasional (RDBMS) dari Microsoft. Bahasa query utamanya adalah Transact-SQL yang merupakan implementasi dari SQL standar ANSI/ISO yang digunakan oleh Microsoft dan Sybase. Umumnya SQL Server digunakan di dunia bisnis yang memiliki basis data berskala kecil sampai dengan menengah, tetapi kemudian berkembang dengan digunakannya SQL Server pada basis data besar.

\section{F. Wireless Access Point}

Dalam jaringan komputer, wireless access point (titik akses nirkabel) adalah suatu piranti yang memungkinkan piranti nirkabel untuk terhubung ke dalam jaringan dengan menggunakan Wi-Fi, Bluetooth, atau standar lain. Wireless access point biasanya tersambung ke suatu router (melalui kabel) sehingga dapat meneruskan data antara berbagai perangkat nirkabel (seperti komputer atau printer) dengan jaringan berkabel pada suatu jaringan. Standar yang diterapkan untuk wireless access point ditetapkan oleh IEEE dan sebagian besar menggunakan IEEE 802.11 [5].

\section{G. $W i-F i$}

$\mathrm{Wi}-\mathrm{Fi}$ adalah teknologi jaringan nirkabel yang memungkinkan komputer dan perangkat lain untuk berkomunikasi melalui sinyal nirkabel. Ini menggambarkan komponen jaringan yang berbasis pada salah satu standar 802.11 yang dikembangkan oleh IEEE dan diadopsi oleh $\mathrm{Wi}$-Fi Alliance [6].

\section{H. Teori Euclidean Distance}

Euclidean distance [7] adalah perhitungan jarak dari 2 buah titik dalam Euclidean Space. Euclidean space diperkenalkan

$$
d=\sqrt{\left(x_{1}-x_{2}\right)^{2}+\left(y_{1}-y_{2}\right)^{2}}
$$

Keterangan:

$d=$ jarak antara 2 titik. $x_{1}=$ sumbu koordinat $\mathrm{x}$ pada titik ke- 1 .

$x_{2}=$ sumbu koordinat $\mathrm{x}$ pada titik ke- 2 .

$y_{1}=$ sumbu koordinat y pada titik ke- 1 .

$y_{2}=$ sumbu koordinat y pada titik ke- 2 .

Tabel 1.

Parameter Kekuatan Sinyal Wi-Fi

\begin{tabular}{ccc}
\hline \hline $\begin{array}{c}\text { Tingkat Kuat } \\
\text { Sinyal (bar sinyal) }\end{array}$ & Kategori & $\begin{array}{c}\text { Nilai Kuat } \\
\text { Sinyal }(\mathrm{dBm})\end{array}$ \\
\hline 5 & Excellent & $>-60$ \\
4 & Good & $-60 \mathrm{~s} / \mathrm{d}-70$ \\
3 & Fair & $-71 \mathrm{~s} / \mathrm{d}-80$ \\
2 & Bad & $-81 \mathrm{~s} / \mathrm{d}-90$ \\
1 & Very Bad & $<-90$ \\
\hline \hline
\end{tabular}

oleh Euclid seorang matematikawan dari Yunani untuk mempelajari hubungan antara sudut dan jarak. Teori ini berkaitan dengan Teorema Pythagoras dan biasanya diterapkan pada titik 1 dan 2 dimensi. Teori Euclidean distance didefinisikan pada (1).

\section{Parameter Kekuatan Sinyal Wi-Fi}

Kualitas sinyal Wi-Fi [8] dapat dikategorikan berdasarkan kualitasnya seperti pada Tabel 1.

\section{J. Algoritma Clustering Filtered K-Nearest Neighbors (CFK)}

Clustering Filtered k-Nearest Neighbors (CFK) [9] merupakan gabungan antara klasifikasi KNN ( $k$-Nearest Neighbors) dan Hierarchical Clustering. CFK menggunakan teknik pengelompokan dalam pembagian tetangga menjadi beberapa kelompok dan hanya satu kelompok yang digunakan, sementara yang lain dikeluarkan. Berikut merupakan tahapantahapan algoritma Clustering Filtered $k$-Nearest Neighbors:

1. Pada ruang sampel $\mathrm{S}$, dilakukan klasifikasi KNN dengan nilai $\mathrm{k}$ yang sudah ditentukan, lalu ditemukan kumpulan sampel K terdekat berdasarkan jaraknya (dengan Euclidean Distance) yang dinamakan K_SetL.

2. Menerapkan algoritma Hierarchical Clustering pada K_SetL, yaitu mencari sepasang sampel dengan nilai distance terdekat, lalu menggabungkannya menjadi satu cluster. Proses tersebut dilakukan terus menerus hingga nilai distance pada semua cluster tidak ada yang di bawah threshold.

3. Dari beberapa cluster yang telah diproses, akan diterapkan aturan sebagai berikut:

a. Ambil jarak cluster yang paling dekat.

b. Jika terdapat cluster terdekat dengan jarak yang sama lebih dari satu, maka ambil cluster yang memiliki anggota data sample yang lebih banyak.

4. Menurut aturan tersebut, pilih salah satu cluster yang menjadi wakil dari semua cluster, yang akan disebut sebagai cluster $\mathrm{C}$ atau delegated cluster.

5. Hitung rata-rata posisi koordinat dari semua sampel di dalam $\mathrm{C}$ sebagai perkiraan lokasinya. 


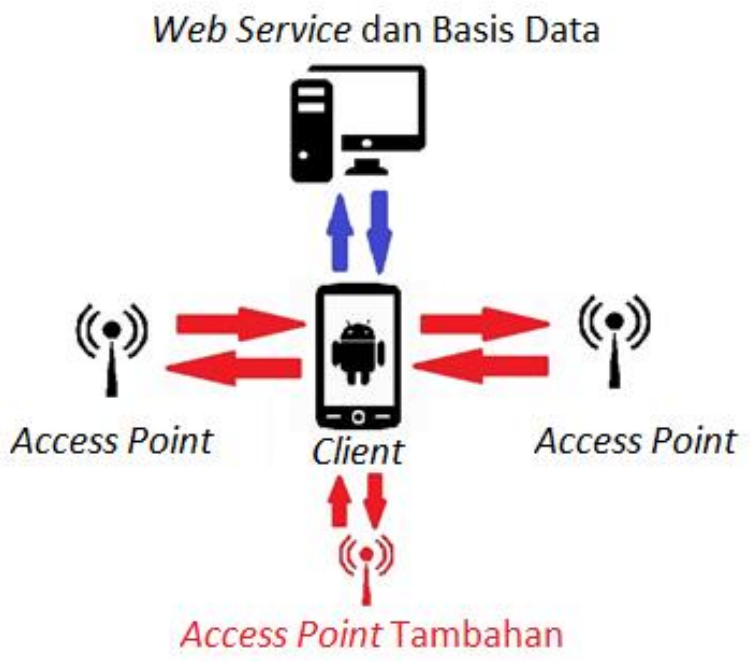

Gambar 1. Arsitektur Sistem

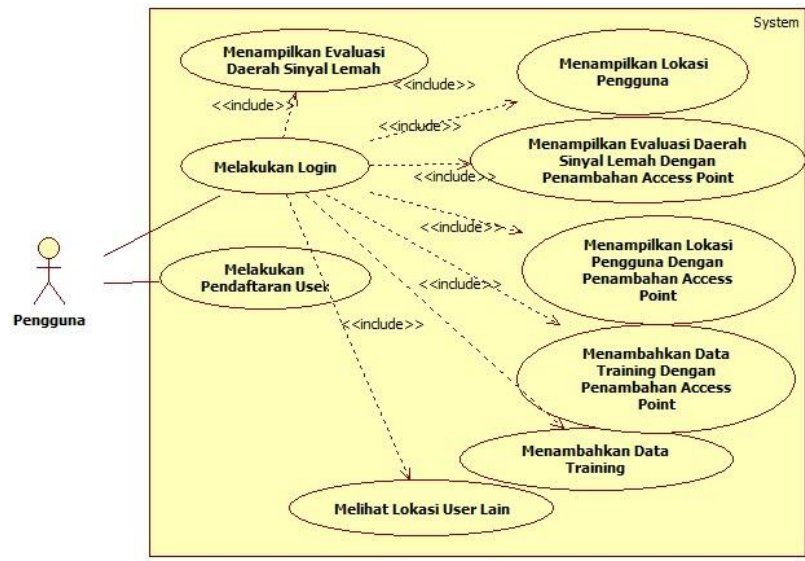

Gambar 2. Diagram Kasus Penggunaan

\section{ANALISIS DAN PERANCANGAN}

\section{A. Arsitektur Sistem}

Arsitektur sistem pada aplikasi tugas akhir ini dijelaskan pada Gambar 1. Sistem Indoor Positioning System dengan penambahan access point ini menggunakan arsitektur clientserver. Server merupakan web service dan database server, sedangkan client merupakan aplikasi pada smartphone berbasis Android. Server sistem Indoor Positioning System menggunakan sinyal Wi-Fi. Sistem tersebut digunakan untuk mengetahui posisi pengguna dengan dua data sampel berbeda untuk membandingkan tingkat akurasi. Client bertugas mengumpulkan data dari access point biasa dan access point tambahan, mengirimkan data ke server, menampilkan informasi terkait area gedung yang memiliki jangkauan sinyal $\mathrm{Wi}$-Fi lemah.

\section{B. Perancangan Sistem}

Berdasarkan deskripsi umum sistem pada pendahuluan, didapatkan beberapa kebutuhan fungsional yang diperlukan untuk membangun aplikasi indoor positioning ini. Diagram kasus penggunaan aplikasi dapat dilihat pada Gambar 2.

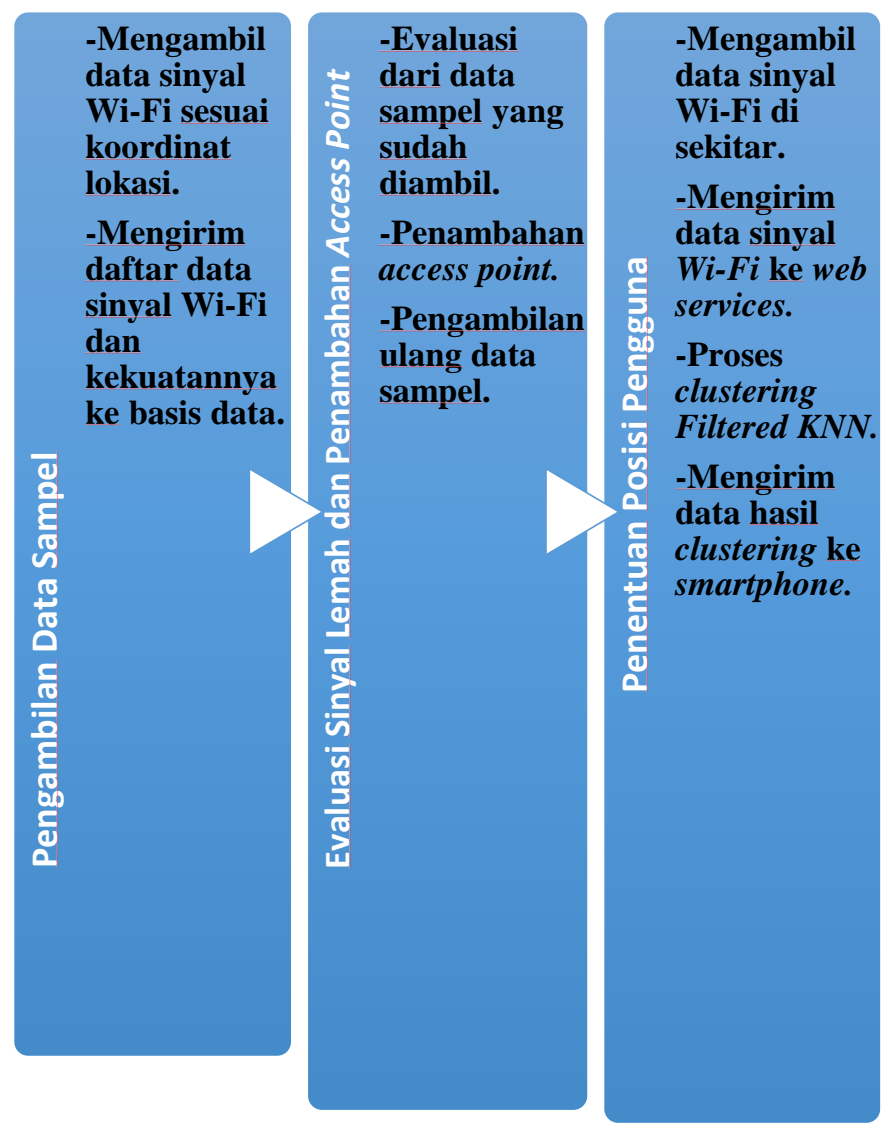

Gambar 3. Alur Sistem

\section{Perancangan Alur Sistem}

Proses alur yang dibangun pada sistem ini meliputi proses pengumpulan data sampel, proses evaluasi sinyal lemah dan penambahan access point, serta proses penentuan lokasi pengguna.

Alur sistem dapat dilihat pada Gambar 3. Pada gambar tersebut, alur sistem dimulai dengan pengambilan data sampel. Data sampel diambil dengan cara mengambil data-data Received Signal Strength (RSS) sesuai koordinat lokasi dan mengirimkannya ke basis data. Kemudian dari data sampel yang sudah diambil, dilakukan evaluasi lokasi yang memiliki cakupan sinyal access point dengan kekuatan lemah, setelah itu dilakukan penambahan access point di beberapa lokasi tersebut dan dilakukan pengambilan ulang data sampel. Setelah proses penambahan access point dilakukan, maka proses penentuan lokasi pengguna bisa dilakukan dengan mengirim data-data RSS di lokasi pengguna ke server untuk diproses dengan clustering Filtered KNN.

\section{IMPLEMENTASI SISTEM}

\section{A. Implementasi Antarmuka}

Halaman login dan register dapat dilihat pada Gambar 4. Halaman login digunakan untuk memverifikasi akun pengguna agar dapat mengakses fungsionalitas utama sistem, sedangkan halaman register digunakan untuk melakukan pendaftaran pengguna baru. 


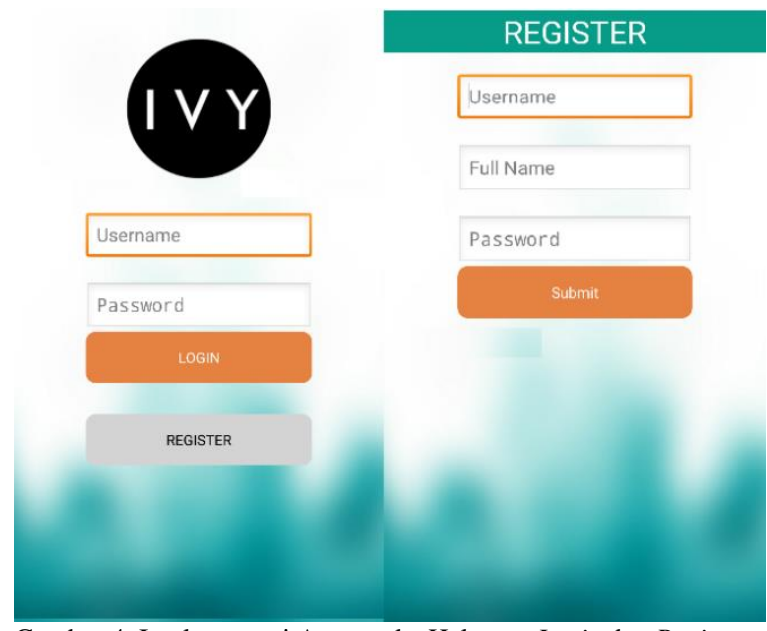

Gambar 4. Implementasi Antarmuka Halaman Login dan Register

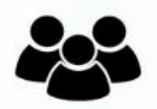

Looking for Other User

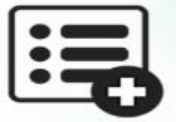

Insert Training Insert Training Data

Data

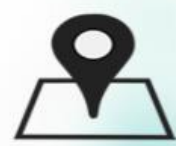

Position

Detector

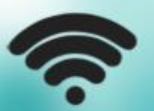

Low Signal

Evaluation

Access Point +

Gambar 5. Implementasi Antarmuka Halaman Utama
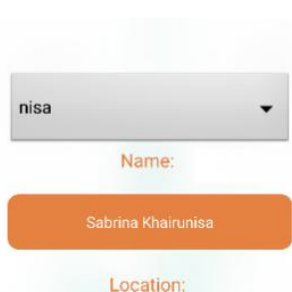

Location:

[Jalan] Samping Lab DTK

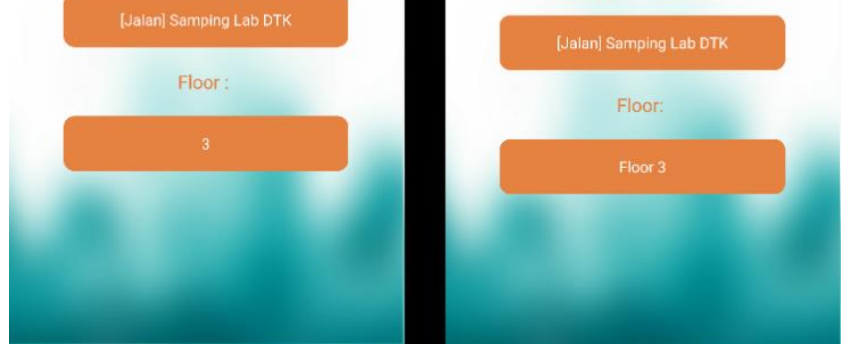

Gambar 6. Implementasi Antarmuka Halaman Melihat Lokasi User Lain dan Halaman Mendapatkan Lokasi

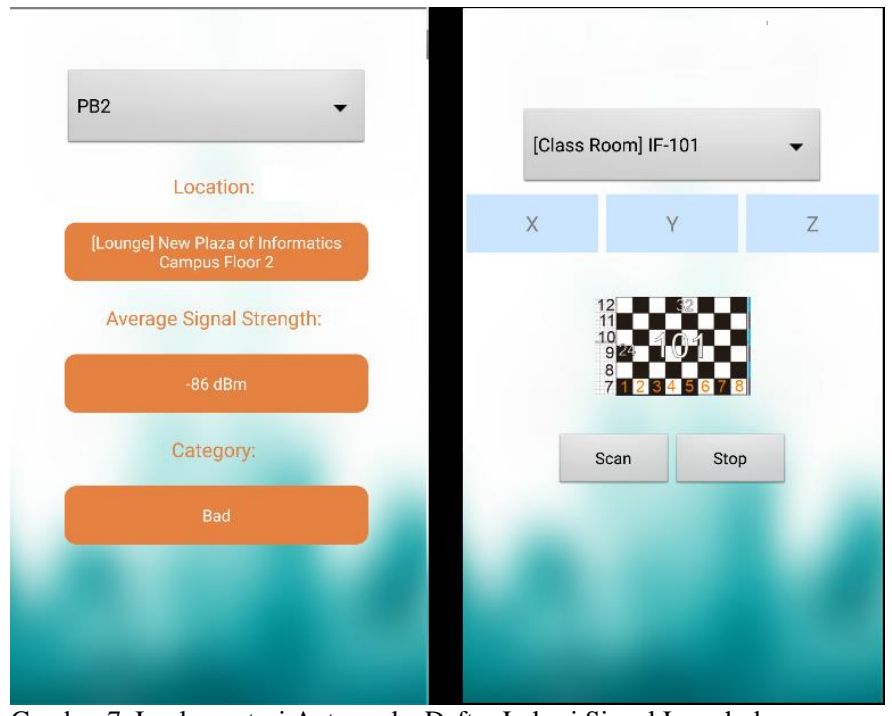

Gambar 7. Implementasi Antarmuka Daftar Lokasi Sinyal Lemah dan Halaman Tambah Data Training

\begin{tabular}{|l|l|l|}
\hline Id & Name & Description \\
\hline KANTIN & Kantin & Kantin \\
\hline KANTINHIMA & [Kantin] Kantin lantai 3 & Kantin lantai 3 \\
\hline PB2 & [Lounge] New Plaza of Informatics Campus Floor 2 & Lounge \\
\hline PB3 & [Lounge] Plasa baru lantai 3 & Lounge \\
\hline PL1 & [Lounge] Old Plaza of Informatics Campus Floor 1 & Lounge \\
\hline PLASADTK & [Jalan] Samping Lab DTK & Jalan \\
\hline PLASAPIKTI & [Lounge] Plasa Pikti & Lounge \\
\hline
\end{tabular}

Gambar 8. Hasil Pengolahan Data Evaluasi Sinyal Lemah

Halaman utama aplikasi dapat dilihat pada Gambar 5. Halaman melihat lokasi user lain dan halaman mendapatkan lokasi dapat dilihat pada Gambar 6. Halaman melihat lokasi user lain digunakan untuk melihat lokasi pengguna lain yang menggunakan sistem ini, sedangkan halaman mendapatkan lokasi digunakan untuk mencari lokasi pengguna untuk saat ini.

Halaman daftar lokasi sinyal lemah dan halaman tambah data training dapat dilihat pada Gambar 7. Halaman daftar lokasi sinyal lemah digunakan untuk melihat titik lokasi mana saja yang memiliki cakupan sinyal access point dengan kekuatan lemah, sedangkan halaman tambah data training digunakan untuk melakukan pengambilan data sampel.

B. Implementasi Evaluasi Sinyal Lemah dan Penambahan Access Point

Untuk menentukan lokasi pemasangan access point, diperlukannya analisis terhadap lokasi pemasangan access point yang sudah ada, yaitu dengan cara melakukan pengolahan data terhadap semua data sampel yang sudah masuk. Data lokasi dipilih dengan query agar memenuhi kriteria berikut:

1. Tidak memiliki cakupan terhadap access point dengan kekuatan sinyal berkategori Excellent (lebih besar dari $60 \mathrm{dBm})$.

2. Memiliki kekuatan sinyal dengan kategori Bad (antara $81 \mathrm{dBm}$ sampai dengan $-90 \mathrm{dBm}$ ) atau Very Bad (lebih kecil dari $-90 \mathrm{dBm})$.

Hasil dari pengolahan query tersebut menghasilkan sejumlah titik lokasi seperti pada Gambar 8. 
Tabel 2.

Daftar Device Penambahan Access Point

\begin{tabular}{|c|c|c|c|c|}
\hline No. & Jenis & Model & Nama SSID & $\begin{array}{c}\text { Lokasi } \\
\text { Dipasang }\end{array}$ \\
\hline 1. & Smartphone & $\begin{array}{c}\text { Nokia Lumia } \\
720\end{array}$ & Sandylumia & Plasa DTK \\
\hline 2. & Router & $\begin{array}{l}\text { TP LINK- } \\
\text { MR3020 }\end{array}$ & $\begin{array}{c}\text { TP- } \\
\text { LINK_Pocket } \\
\text {-3020_79201 } \\
\text { A }\end{array}$ & Plasa PIKTI \\
\hline 3. & Smartphone & $\begin{array}{c}\text { Samsung } \\
\text { Galaxy Grand } \\
\text { I9082 }\end{array}$ & Samsungifan & Plasa Baru 3 \\
\hline 4. & Smartphone & $\begin{array}{c}\text { Samsung } \\
\text { Galaxy Tab } 3 \\
7.0 \\
\text { BlackBerry }\end{array}$ & Adittab & Plasa Baru 2 \\
\hline 5. & Smartphone & $\begin{array}{l}\text { Bold Touch } \\
\quad 9900\end{array}$ & Adityabb & Kantin hima \\
\hline 6. & Smartphone & $\begin{array}{c}\text { Nokia Lumia } \\
800\end{array}$ & $\begin{array}{c}\text { Nokia Lumia } \\
800 \_0192\end{array}$ & Plasa Lama 1 \\
\hline 7. & Smartphone & $\begin{array}{c}\text { Sony } \\
\text { Ericsson } \\
\text { Xperia Mini }\end{array}$ & $\begin{array}{l}\text { xperia mini } \\
\text { fandy }\end{array}$ & Kantin \\
\hline
\end{tabular}

Tabel 3.

Hasil Pengujian Fungsionalitas

\begin{tabular}{clc}
\hline \hline No & \multicolumn{1}{c}{ Nama Pengujian } & Hasil Pengujian \\
\hline 1. & Melakukan Login & Berhasil \\
2. & Melakukan Pendaftaran User & Berhasil \\
3. & $\begin{array}{l}\text { Menampilkan Evaluasi Daerah Sinyal } \\
\text { Lemah }\end{array}$ & Berhasil \\
& $\begin{array}{l}\text { Menampilkan Evaluasi Daerah Sinyal } \\
\text { 4. }\end{array}$ & $\begin{array}{l}\text { Lemah Dengan Penambahan Access } \\
\text { Point }\end{array}$ \\
5. & Menampilkan Lokasi Pengguna & Berhasil \\
6. & Menampilkan Lokasi Pengguna & Dengan Access Point \\
7. & $\begin{array}{l}\text { Menambahkan Data Training } \\
\text { 8. }\end{array}$ & Menambahkan Data Training Dengan \\
9. & Menambahan Access Point & Berhasil \\
\hline \hline
\end{tabular}

Tabel 4.

Hasil Pengujian Akurasi

\begin{tabular}{|c|c|c|c|c|}
\hline No & Lokasi Pengujian & Sebelum & Sesudah & Selisih \\
\hline 1. & Kelas IF-101 & $67,5 \%$ & $92,5 \%$ & $25,00 \%$ \\
\hline 2. & Kelas IF-102 & $92,5 \%$ & $97,5 \%$ & $5,00 \%$ \\
\hline 3. & Kelas IF-103 & $100 \%$ & $100 \%$ & $0,00 \%$ \\
\hline 4. & Kelas IF-104 & $85 \%$ & $92,5 \%$ & $7,5 \%$ \\
\hline 5. & Kelas IF-105A & $67,5 \%$ & $97,5 \%$ & $30,00 \%$ \\
\hline 6. & Kelas IF-105B & $100 \%$ & $100,00 \%$ & $0,00 \%$ \\
\hline 7. & Kelas IF-106 & $60 \%$ & $97,5 \%$ & $37,5 \%$ \\
\hline 8. & Kelas IF-108 & $82,5 \%$ & $90,00 \%$ & $7,5 \%$ \\
\hline 9. & Kelas IF-111 & $100 \%$ & $100,00 \%$ & $0,00 \%$ \\
\hline 10. & Kelas IF-112 & $87,5 \%$ & $92,5 \%$ & $5,00 \%$ \\
\hline 11. & $\begin{array}{l}\text { Ruang Baca Teknik } \\
\text { Informatika }\end{array}$ & $91,25 \%$ & $92,5 \%$ & $1,25 \%$ \\
\hline 12. & Depan Kantin & $40 \%$ & $96,67 \%$ & $56,67 \%$ \\
\hline 13. & Plasa PIKTI & $56,67 \%$ & $96,67 \%$ & $40,00 \%$ \\
\hline 14. & Plasa Lama 1 & $46,67 \%$ & $96,67 \%$ & $50,00 \%$ \\
\hline 15. & Plasa Baru 1 & $86,67 \%$ & $86,67 \%$ & $0,00 \%$ \\
\hline 16. & Laboratorium IGS & $92,5 \%$ & $97,5 \%$ & $5,00 \%$ \\
\hline 17. & Plasa Baru 3 & $66,67 \%$ & $96,67 \%$ & $30,00 \%$ \\
\hline 18. & $\begin{array}{l}\text { Laboratorium } \\
\text { Pemrograman } 2\end{array}$ & $83,75 \%$ & $95,00 \%$ & $11,25 \%$ \\
\hline 19. & $\begin{array}{l}\text { Laboratorium Algoritma } \\
\text { dan Pemrograman }\end{array}$ & $100 \%$ & $100,00 \%$ & $0,00 \%$ \\
\hline 20. & $\begin{array}{l}\text { Laboratorium Manajemen } \\
\text { Informasi }\end{array}$ & $95 \%$ & $95,00 \%$ & $0,00 \%$ \\
\hline 21. & $\begin{array}{l}\text { Laboratorium Dasar } \\
\text { Terapan Komputasi }\end{array}$ & $75 \%$ & $90,00 \%$ & $15,00 \%$ \\
\hline
\end{tabular}

\begin{tabular}{llccc}
\hline \hline 22. & Lorong Lab MI dan DTK & $70 \%$ & $100,00 \%$ & $30,00 \%$ \\
23. & Plasa DTK & $63,34 \%$ & $90,00 \%$ & $26,66 \%$ \\
& Rata-Rata & $78,7 \%$ & $95,36 \%$ & $16,67 \%$ \\
\hline \hline
\end{tabular}

Dari hasil pengolahan query, maka dilakukan penambahan access point berupa router atau smartphone yang bisa memancarkan sinyal Wi-Fi untuk membantu meningkatkan cakupan kekuatan sinyal access point di titik-titik lokasi tersebut seperti pada Tabel 2.

\section{PENGUJIAN}

Pengujian terhadap sistem yang telah selesai dibangun meliputi pengujian fungsionalitas dan pengujian akurasi. Pengujian fungsionalitas dilakukan dengan metode blackbox. Sedangkan pengujian akurasi terdapat 23 ruangan lokasi di Gedung Teknik Informatika ITS yang digunakan untuk proses pengujian akurasi.

Pengujian akurasi dilakukan dengan cara menggunakan aplikasi untuk melakukan deteksi lokasi ketika sebelum dilakukan penambahan access point dan ketika setelah penambahan access point. Pengujian ini bertujuan untuk mengukur tingkat akurasi sistem dalam melakukan perkiraan lokasi dan membandingkannya jika tidak menggunakan tambahan access point. Hasil dari pengujian fungsionalitas ditunjukkan pada Tabel 3 dan hasil dari pengujian akurasi ditunjukkan pada Tabel 4.

\section{KESIMPULAN}

Selama proses perancangan, implementasi, dan pengujian dapat diambil kesimpulan sebagai berikut:

1. Proses prediksi lokasi pengguna dilakukan dengan memproses sinyal $\mathrm{Wi}-\mathrm{Fi}$ di sekitar pengguna menjadi informasi lokasi dengan algoritma Clustering Filtered KNN dan penambahan access point dapat dijalankan dengan baik.

2. Penelitian ini berhasil menerapkan sistem indoor positioning dengan penambahan access point dengan persentase rata-rata akurasi seluruh ruangan sebesar 95,36\%, naik sebesar $16,67 \%$ dari akurasi ketika tidak dilakukan penambahan access point.

3. Secara keseluruhan persebaran Wi-Fi di Gedung Teknik Informatika sudah cukup bagus dan merata karena sebagian besar ruangan sudah tercakup access point dengan baik, hanya sebagian sudut-sudut ruangan saja yang memiliki cakupan sinyal lemah.

4. Penambahan access point lebih efisien dalam meningkatkan akurasi dan konsistensi hasil dari sistem indoor positioning.

\section{UCAPAN TERIMA KASIH}

Penulis F.H.P. mengucapkan terima kasih kepada Jurusan Teknik Informatika Institut Teknologi Sepuluh Nopember atas segala bantuan dan bimbingannya dalam menempuh ilmu dan meraih gelar Sarjana dalam tahun 2012-2016.

\section{DAFTAR PUSTAKA}

[1] S. Steiniger, M. Neun and A. Edwardes, "Foundations of Location Based Services," Lecture Notes on LBS, vol. 1.0, pp. 1-8, 2006. 
[2] M. F. Ghanianto, Implementasi Indoor Localization Menggunakan Sinyal Wifi dan Clustering Filtered K-Nearest Neighbors untuk Pelacakan Keberadaan Seseorang dan Evaluasi Akurasi Pelacakan di Kampus Teknik Informatika ITS, Surabaya, 2015.

[3] "Pengenalan Android Studio," [Online]. Available: http://www.jadibaru.com/android/pengenalan-android-studio-2/. [Accessed 3 March 2016].

[4] "Microsoft SQL Server," [Online]. Available: https://id.wikipedia.org/wiki/Microsoft_SQL_Server. [Accessed 2016 April 2].

[5] "Titik akses nirkabel," [Online]. Available: https://id.wikipedia.org/wiki/Titik_akses_nirkabel. [Accessed 14 Desember 2015].

[6] "Wi-Fi - IEEE Standards," Tutorialspoint, [Online]. Available: http://www.tutorialspoint.com/wi-fi/wifi_ieee_standards.htm. [Accessed 3 December 2015].

[7] "Cara Menghitung Euclidean Distance," 7 November 2012. [Online]. Available: http://itmbali.blogspot.co.id/2012/11/euclidean-distance.html. [Accessed 4 April 2016].

[8] N. Sarkar, "Qualitative Characterization of Wireless Channel," in Improving the Performance of Wireless LANs: A Practical Guide, New York, Taylor \& Francis, 2014, p. 464.

[9] J. Ma, X. Li, X. Tao and J. Lu, "Cluster Filtered KNN: A WLAN-Based Indoor Positioning Scheme," in World of Wireless, Mobile and Multimedia Networks, 2008. WoWMoM 2008. 2008 International Symposium on a, Newport Beach, CA, 2008, pp. 1-8. 